năng lây truyền cao; $52,2 \%$ biết tiêm vắc xin sởi có thể phòng được bệnh; $34,0 \%$ bà me biết miễn dịch của mẹ truyền cho trẻ có thể bảo vệ trong khoảng 6-9 tháng ${ }^{4}$.

Đồng thời qua nghiên cứu này cũng cho biết vẫn còn nhiều đối tượng tham gia nghiên cứu trả lời không biết về những hiểu biết về bệnh sởi, kiến thức trả lời không biết nhiều nhất là Miễn dịch của mẹ truyền cho trẻ có thể bảo vệ trong khoảng 6-9 tháng chiếm tỷ lệ 27,2\%. Trẻ dưới 9 tháng tuổi là trẻ chưa đến tuổi tiêm chủng vắc xin sởi. Vì thông thường trẻ dưới 9 tháng tuổi được bảo vệ bởi kháng thể của mẹ truyền sang con. Do đó, trẻ trong giai đoạn tuổi này có thể bị nhiễm sởi bởi các lý do như: Thứ nhất, nếu bà me của những trẻ này chưa có miễn dịch với sởi (chưa bị sởi, chưa tiêm phòng sởi, hoặc miễn dịch sởi yếu do tiêm vắc xin sởi không đủ đáp ứng) thì trẻ sinh ra sẽ không có miễn dịch sởi; thứ hai là me có miễn dich sởi nhưng khổng cho con bú; thứ ba là hệ miễn dịch của trẻ không đủ duy trì nồng độ kháng thể trong thời gian dài. Do đó, ở nhóm trẻ dưới 9 tháng tuổi vẩn gặp mắc sởi với một tỉ lệ nhất định. Việc phát hiện sớm và điều trị kịp thời đóng vai trò quan trọng để ngăn chặn những biến chứng do sởi gây ra, đồng thời có biện pháp cách ly, ngăn chặn việc lây lan thành dịch bênh. Theo kết quả nghiên cứu giám sát của viện Vệ sinh dịch tễ Trung ương năm 2013, tỉ lệ trẻ mắc bệnh sởi trong số các trường hợp có sốt phát ban nghi sởi rất cao trên $70 \%^{3}$.

\section{KẾT LUÂ̂N}

94,2\% đã nghe nói về bệnh sởi, chủ yếu từ nguồn thông tin đại chúng. $91 \%$ đối tượng biết bệnh sởi có khả năng lây truyền; $85,4 \%$ biết bệnh sởi lây theo đường hô hấp và $94,7 \%$ đối tượng biết mức độ nguy hiểm của bệnh sởi. Kiến thức phòng chống bệnh sởi của đối tượng nghiên cứu còn ở mức thấp, chỉ có 33,3\% đối tượng có kiến thức tốt. Kiến thức thực hành phòng chống bênh sởi chưa cao, chỉ có $23,8 \%$ các đối tượng có kiến thức thực hành tốt về phòng chống bệnh sởi. 18,5\% đối tượng tham gia nghiên cứu có tiêm phòng sởi trước khi mang thai.

\section{TÀI LIỆU THAM KHẢO}

1. Bô Y Y tế. Cẩm nang phòng chống bênh truyền nhiễm. Bệnh Sởi, Hà Nội, 2009; 222-8

2. WHO. Weekly Epidemiologitrường hợpl Record. 2009

3. Viện vệ sinh Dịch tề Trung ương: Tổng kết Tiểm chủng mở rộng năm 2014. Dự án tiêm chủng mở rộng. 2015

4. WHO. Measles Fact sheet 2017 [18/02/2018] http://www.who.int/mediacentre/Factsheets/fs286/en/

5. Leuridan $E$, Hens $N$, Hutse $V$, Leven $M$, Van Damme P. Early waning of maternal measles antibodies in era of measles elimination: longitudinal study. BMJ, 2010; 340: 1-7. Francis L.Black (1966), "Measles", Springer, tr. 397-398.

6. Trung tâm Y tế thị xã Từ Sơn: Báo cáo tổng kết năm 2018, 2019.

7. Đoàn Văn Dương. Thức trang dich sởi, công tác đáp ứng phòng chống dịch và̀ kiến thức, thực hành của bà me về bệnh sởi tại 5 xã của huyện Ngọc Lăc, tỉnh Thanh Hóa năm 2016. Luân văn thạc sĩ Y tể công công, Trường Đại học Y Dược Thái Bình. 2017

8. http://tuison.bacninh.gov.vn

9. Herch BS, Olive JM và CS, "Meales elimination in the Ameritrường hợps: evolving strategies". JAMA, 1996; 275 (3): 224 - 229.

\title{
ĐÁNH GIÁ NỒNG Độ ACID URIC MÁU Ở BÊNH NHÂN VIÊM THẬN LUPUS VÀ MộT SỐ YẾU TỐ LIÊN QUAN
}

\section{TÓM TẮT}

Mục tiêu: Khảo sát nồng độ acid uric máu ở bệnh nhân viêm thận Lupus và tìm hiểu mối liên quan giữa tăng acid uric máu và một số yếu tố lâm sàng và cận lâm sàng ở nhóm bệnh nhân. Đối tượng và phươning pháp nghiên cứu: Nghiên cứu mô tả cắt ngang, hồi cứu và tiến cứu trên 117 bệnh nhân viêm thận lupus

\footnotetext{
${ }^{1}$ Trường Đại Học Y Hà Nội

${ }^{2}$ Tt Thận - tiết niệu và Lơc máu, Bệnh viện Bạch Mai Chịu trách nhiệm chính: Nguyễn Thị Lệ Mỹ

Email: nguyenthilemy19121995@gmail.com

Ngày nhận bài: 20.8.2021

Ngày phản biên khoa hoc: 19.10.2021

Ngày duyệt bài: 29.10.2021
}

\section{Nguyễn Thị Lệ Mỹ', Đặng Thị Việt Hà ${ }^{1,2}$, Đỗ Gia Tuyển 1,2}

điều trị tại Trung tâm Thận - Tiết niệu và lọc máu bệnh viện Bạch Mai từ tháng 01/2020 đến 08/2021. Kết quả: 117 bênh nhân nghiên cứu có tuổi trung bình là $34.6 \pm 1.11$, với tỷ lệ nam/nữ là $1 / 9.64$ và $35.9 \%$ bệnh nhân phát hiện bệnh trong 1 tháng. Tỷ lệ tăng acid uric máu chiếm $75.2 \%$, nồng độ trung bình là $463.60 \pm 1.03$. Tỷ lệ tăng acid uric ở nữ cao hơn nam có ý nghĩa thống kê $(p<0.01)$ nhưng nồng độ acid uric ở 2 giới thì không có sự khác biệt $(p>0.05)$. Các triệu chứng như tràn dịch màng tim (57.7\%), tăng huyết áp (56.4\%), hôi chứng thân hư (57.3\%) thiếu máu $(87.2 \%)$ có sự khác biệt có ý nghĩa thống kê giữa 2 nhóm tăng acid uric và không tăng acid uric $(p<0.05)$. Trên sinh thiết thận ở 46 bệnh nhân, tỷ lệ class III, IV là $30.6 \%, 61.1 \%$, nồng độ acid uric trung bình: $415.18 \pm 102.025$ và $503.76 \pm 105.190$, có sự khác 
biệt có ý nghĩa thống kê với $\mathrm{p}=0.019$. Acid uric có mối tương quan thuận với chỉ số huyết áp tâm thu, tâm trương, áp lực động mạch phổi, creatinine máu, ferritin, anti-ANA, protein niệu với $r=0.188 ; 0.210$; $0.242,0.476 ; 0.265 ; 0.206 ; 0.226(p<0.05)$ và tương quan nghịch với mức lọc câuu thận, pH niệu, hemoglobin, protein, C3 với $r=-0.457 ;-0.241$; $0.204,-0.261,-0.331(\mathrm{p}<0.05)$. Acid uric và mức đô hoat động bênh dựa trên thang điểm SLEDAI có mổi tưởng quan thuận với với với hệ số tương quan $r$ $=0,388(p<0,001)$. Nồng độ acid uric ở những bệnh nhân có tăng áp động mạch phổi $>40 \mathrm{mmHg}$ cao hơon

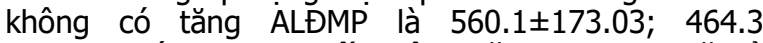
\pm 131.31 với $p<0.05$. Kết luận: Tăng acid uric gặp ở $75.2 \%$ bênh nhân viêm thân lupus, dự báo tiến triển xấu của viêm thận lupus và các biến chứng của bệnh (mức MLCT thấp hơn, thiếu máu hơn, huyết áp tăng, mức độ hoạt động bệnh SLEDAI cao hơn...). Việc giứ nồng độ acid uric thấp được khuyến cáo giúp tránh các biến chứng trong viêm thận lupus và nồng độ acid uric huyết thanh nên được áp dụng trong thực hành y tế khi đánh giá bệnh nhân VTL.

Tư khóa: Tăng acid uric, Viêm thận lupus, mức độ hoạt động, SLEDAI, suy thận

\section{SUMMARY}

\section{INVESTIGATING LEVELS OF ACID URIC IN PATIENTS WITH LUPUS NEPHRITIS AND} SOME RELATED FACTORS

Objectives: Investigating levels of acid uric in patients with lupus nephritis and the relationship between hyperuremia and some clinical, subclinical factors in this patient group. Subjects and methods: A cross-sectional, retrospective and prospective study on 117 lupus nephritis patients treated in Nephro - Urology and Dialysis Center, Bach Mai hospital from 01/2020 to 08/2021. Results: 117 study patients have an average age of $34.6 \pm 1.11$, with a male: female ratio of $1: 9.64$, and $35.9 \%$ of patients have detected the disease in 1 month. The rate of hyperuricemia accounted for $75.2 \%$, the average concentration was $463.60 \pm 13.03$. The rate of increased uric acid in women was higher than in men, with statistical significance $(p<0.01)$ although uric acid levels in the two sexes were not different $(p>0.05)$. Symptoms such as pericardial effusion $(57.7 \%)$, hypertension $(56.4 \%)$, nephrotic syndrome $(57.3 \%)$, anemia $(87.2 \%)$ had a statistically significant difference between the 2 groups of hyperuricemia acid and non-hyperuricemia $(p<0.05)$. On kidney biopsies in 46 patients, the rate of class III, IV was $30.6 \%$, $61.1 \%$, average uric acid concentration: $415.18 \pm 102.025$ and $503.76 \pm 105.190$, there was a statistically significant difference with $p=0.019$. Uric acid has a positive correlation with systolic blood pressure, pulmonary arterial pressure, creatinine, ferritin, anti-ANA, proteinuria with $r=0.188 ; 0.242$; $0.476 ; 0.265 ; 0.206 ; 0.226(p<0.05)$ and negatively correlated with glomerular filtration rate, urinary $\mathrm{pH}$, hemoglobin, protein, $\mathrm{C} 3$ with $r=-0.457$; -0.241 ; $0.204,-0.261,-0.331(p<0.05)$. Uric acid and disease activity levels based on the SLEDAI scale have positively correlated with the correlation coefficient $r=$ $0.388(p<0.001)$. Uric acid levels in patients with pulmonary arterial hypertension $>40 \mathrm{mmHg}$ higher than non-pulmonary arterial hypertension: $560.1 \pm 173.03 ; 464.3 \pm 131.31$ with $p<0.05$. Conclusions: Increased uric acid was found in $75.2 \%$ of patients with lupus nephritis, predicting poor progression of lupus nephritis and complications of the disease (lower eGFR, more anemia, increased blood pressure, higher SLEDAI disease activity levels...) Keeping uric acid levels low is recommended to help avoid complications in lupus nephritis and serum uric acid levels should be adopted in medical practice when evaluating patients with lupus nephritis.

Keywords: Hyperuricemia, Lupus nephritis, disease activity index, SLEDAI, CKD.

\section{I. ĐặT VẤN ĐỀ}

Lupus ban đỏ hệ thống (Systemic Lupus Erythematosus - SLE) là bệnh tự miễn của tổ chức liên kết gây tổn thương nhiều cơ quan thường gặp ở phụ nữ trong độ tuổi sinh đẻ. Trong đó, tổn thương thận hay Viêm thận lupus (VTL) là một trong những biểu hiện phổ biến và là yếu tố chính cho tiên lượng xấu của bệnh. Theo Okba A.M, đến cuối đời hơn một nửa bênh nhân SLE (40-85\%) sẽ phát triển viêm thận lupus trong đó khoảng $25 \%$ tiến triển thành bệnh thận mạn giai đoạn cuối [2]

Acid uric là sản phẩm cuối cùng của quá trình thoái biến purin, có liên quan chặt chẽ với các bệnh như: Gout, Tăng huyết áp, bệnh tim mạch và bệnh thân. Nghiên cứu của Yang năm 2011 ghi nhận nồng độ acid uric huyết thanh có liên quan độc lập đến sự tiến triển của viêm thận lupus và dự đoán sự phát triển tăng áp động mạch phổi (TAĐMP) trong tương lai [3]. Tỷ lệ tăng acid uric ở bệnh nhân viêm thân lupus (40,11\%)[4] cao hớn bệnh nhân ở giai đoạn bệnh thận mạn (CKD) 1-3 thông thường (23,3\%) [5]. Tăng acid uric liên quan đến thiếu máu, biến chứng thần kinh, tăng huyết áp, tăng lipid máu và huyết khối động mạch ở SLE. Việc giữ nồng độ acid uric thấp được khuyến cáo giúp tránh các biến chứng trong SLE [1]. Với những lý do trên, nhằm kiểm soát nồng độ acid uric và các biến chứng, chúng tôi tiến hành nghiên cứu "Đánh giá nồng độ acid uric máu và một số yêu tố liên quan ở bệnh nhân Viêm thânn Lupus"với 2 mục tiêu chính:

1. Khảo sát nông độ acid uric máu trên bệnh nhân Viêm thận Lupus tại trung tâm Thận Tiêt niệu Bệnh viện Bạch Maì từ tháng 01/2020 đến tháng 08/2021.

2. Tìm hiêu môi liên quan giưa nồng độ Acid uric và một số yêu tố lâm sàng và cận lâm sàng ở nhóm bệnh nhân trên. 
II. ĐỐI TƯợNG VÀ PHƯƠNG PHÁP NGHIÊN CỨU

1. Đối tượng nghiên cứu. 117 bệnh nhân được chẩn đoán viêm thận lupus theo tiêu chuẩn ACR 2012 tại trung tâm Thận - Tiết niệu và lọc máu bệnh viên Bạch Mai từ tháng 01/2020 đển tháng $08 / 2021$.

2. Phương pháp nghiên cứu

2.1 Thiết kế nghiến cứu: Mô tả cắt ngang hồi cứu và tiến cứu.

2.2 Các tiêu chuẩn áp dung trong nghiên cứu

- Tiêu chuẩn chẩn đoán lupus ban đỏ hê thống theo SLICC 2012, tiêu chuẩn chẩn đoán viêm thận lupus theo ACR 2012, phân loại tổn thương mô bênh học theo ISN/RPS 2003, đánh giá mức độ hoạt động bệnh theo thang điểm SELENA- SLEDAI

- Tiêu chuẩn chẩn đoán tăng acid uric được định nghĩa là nồng độ acid uric huyết thanh lớn hơn $416 \mu \mathrm{mol} / \mathrm{l}(7 \mathrm{mg} / \mathrm{dl})$ ở nam giới, phụ nữ sau mãn kinh và lớn hơn $357 \mu \mathrm{mol} / \mathrm{l}(6 \mathrm{ml} / \mathrm{dl})$ ở phụ nữ tiền mãn kinh [6]

2.3 Phương pháp phân tích số liệu. Số liệu được quản lý, phân tích bằng phần mềm SPSS 20.0

\section{KẾT QUẢ NGHIÊN CỨU}

1. Đặc điểm chung của nhóm nghiên cứu. Trong số 117 bệnh nhân nghiên cứu, có $90,6 \%$ ( $n=106)$ bệnh nhân nữ, trong đó có 10 người có thai. Đô tuổi trung bình $34.6 \pm 1.11$, tuổi nhỏ nhất là 16 , tuổi lớn nhất là 72 , độ tuối từ 20 đến 49 chiếm $81.2 \%$. Thời gian mắc viêm thân lupus trung bình là $33.9 \pm 4.6$ tháng, có đển $35.9 \%$ bênh nhân được chẩn đoán trong vòng 1 tháng.

\section{Bảng 1. Đặc điểm giới tính và nồng độ acid uric}

\begin{tabular}{|c|c|c|c|c|}
\hline Giới & Acid uric & Tăng Acid uric & Ko tăng Acid uric & P-value \\
\hline Nam & $448.5 \pm 151.67$ & $5(45.5 \%)$ & $6(54.5 \%)$ & \multirow{2}{*}{0.016} \\
\hline Nữ & $465.2 \pm 140.57$ & $83(78.3 \%)$ & $23(21.7 \%)$ & \\
\hline Tống & $463.6 \pm 13.03$ & $88(75.2 \%)$ & $29(26.8 \%)$ & \\
\hline & $\mathrm{p}=0.710$ & & & \\
\hline
\end{tabular}

Nhận xét: Nồng độ acid uric máu trung bình là $463.60 \pm 13.03$, trong đó 75,2\% bệnh nhân có tăng acid uric. Tỷ lệ tăng acid uric ở nữ giới (78.3\%) cao hơn ở nam giới (45.5\%) có ý nghĩa thống kê với độ tin cậy $95 \%(\mathrm{p}=0.016)$. Tuy nhiên không có sự khác biệt có ý nghĩa thống kê về nồng độ acid uric giữa 2 nhóm, $\mathrm{p}=0.710$.

\section{Mối liên quan giữa nồng độ acid uric và các yếu tố lâm sàng, cận lâm sàng}

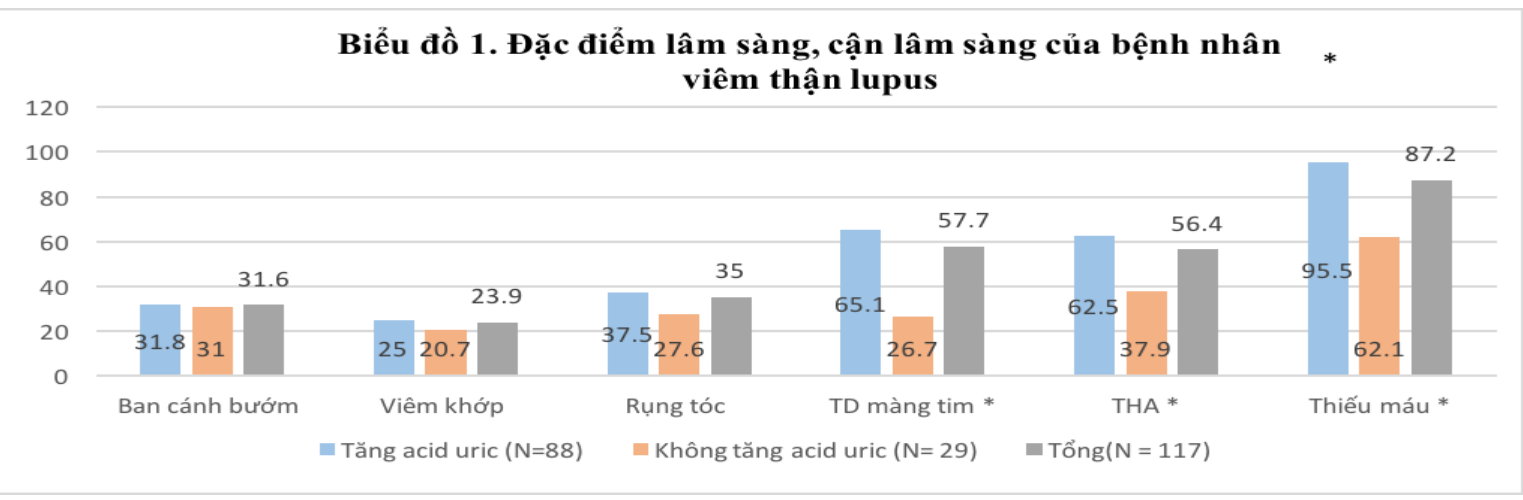

Nhận xét: Các triệu chứng lâm sàng thường gặp là ban cánh bướm (31.6\%), rụng tóc $(35.0 \%)$, sưng đau khớp (23.9\%). Tỷ lệ các triệu chứng này không có sự khác biệt có ý nghĩa thống kê giữa 2 nhóm tăng acid uric và không tăng acid uric. Trong nhóm bệnh nhân có tăng acid uric, tràn dịch màng tim (63.1\%), tăng huyết áp (62.5\%), hội chứng thận hư $(65.9 \%)$, đặc biệt tỷ lệ thiếu máu lên tới $95.5 \%$ và có sự khác biêt có ý nghĩa thống kê với nhóm không tăng acid uric.

Bảng 2. Môi liên quan giữa nồng độ acid uric và mức độ hoạt động bệnh tính theo thang điêm SLEDAI

\begin{tabular}{|c|c|c|c|c|}
\hline $\begin{array}{c}\text { Mức độ hoạt động } \\
\text { (điếm SLEDAI) }\end{array}$ & $\begin{array}{c}\text { Acid uric } \\
(\mathbf{n = 1 1 5})\end{array}$ & $\begin{array}{c}\text { Tăng acid uric } \\
(\mathbf{n}=\mathbf{8 6})\end{array}$ & $\begin{array}{c}\text { Ko tăng acid } \\
\text { uric }(\mathbf{n}=\mathbf{2 8})\end{array}$ & P-value \\
\hline Điểm SLEDAI & $18.46 \pm 4.817$ & $19.79 \pm 3.659$ & $14.39 \pm 5.672$ & $0.000 \mathrm{r}=0.388$ \\
\hline Mức độ nhẹ (1-5) & $285.50 \pm 57.276$ & $0(0 \%)$ & $2(6.9 \%)$ & \multirow{2}{*}{0.000} \\
\hline Mức độ trung bình(6-10) & $281.17 \pm 69.947$ & $0(0 \%)$ & $6(20.7 \%)$ & \\
\hline
\end{tabular}




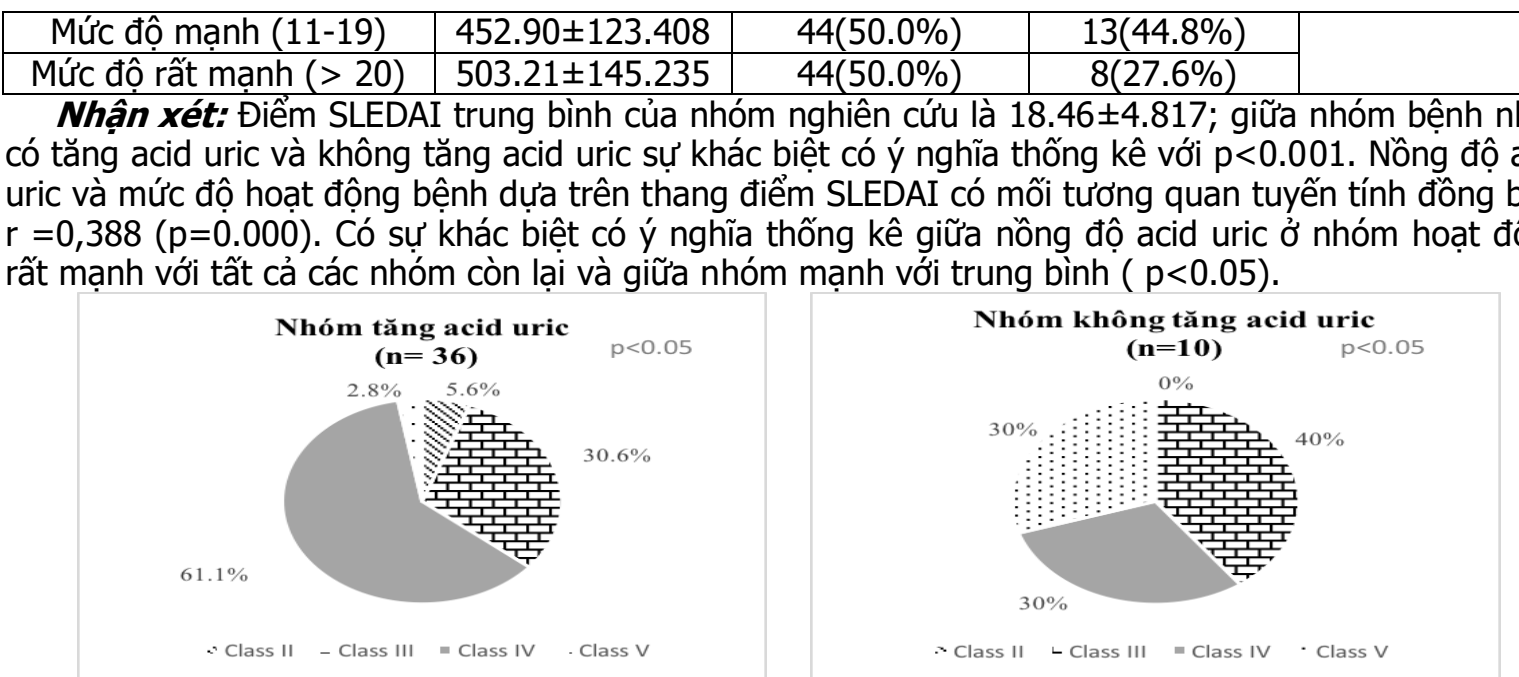
Biểu đồ 2. Tỷ lệ các nhóm mô bệnh học thân giữa 2 nhóm bênh nhân viêm thận lupus có
tăng acid uric và không tăng acid uric

Nhận xét: Trong 46 bệnh nhân được sinh thiết thận, $78.3 \%$ bệnh nhân có tăng nồng độ acid uric và $21.7 \%$ bệnh nhân không tăng acid uric. Có sự khác biệt có ý nghĩa thống kê về tỷ lệ mô bệnh học giữa 2 nhóm tăng acid uric và không tăng acid uric $(p<0,05)$. Ở nhóm các bệnh nhân tăng acid uric tỷ lệ class III, IV chiếm ưu thế với $30.6 \%$ và $61.1 \%$. Nồng độ acid uric trung bình cũng có sự khác biệt giữa các nhóm mô bệnh học, cụ thể là có sự khác biệt giữa class III và class IV nồng độ trung bình: $415.18 \pm 102.025$ và $503.76 \pm 105.190(p=0.019)$

Bảng 3. Mối liên quan giữa tăng huyết áp và một số yêu tố cận lâm sàng.

\begin{tabular}{|c|c|c|c|c|}
\hline $\begin{array}{c}\text { Đặc điếm cận } \\
\text { lâm sàng }\end{array}$ & $\begin{array}{c}\text { Tăng Acid uric } \\
(\mathbf{n}=\mathbf{8 8})\end{array}$ & $\begin{array}{c}\text { Không tăng Acid uric } \\
(\mathbf{n}=\mathbf{2 9})\end{array}$ & $\begin{array}{c}\text { p- } \\
\text { value }\end{array}$ & $\begin{array}{c}\text { Hệ số tương } \\
\text { quan }(\mathbf{r})\end{array}$ \\
\hline BMI & $20.4 \pm 2.40$ & $20.4 \pm 3.08$ & 0.929 & $0.054(p=0.567)$ \\
\hline HATT & $140.9 \pm 22.79$ & $130.4 \pm 23.57$ & 0.031 & $0.199(p=0.031)$ \\
\hline Creatinin & $128.5 \pm 49.19$ & $96.0 \pm 50.20$ & 0.001 & $0.476(p=0.000)$ \\
\hline MLCT & $58.8 \pm 31.26$ & $81.4 \pm 30.96$ & 0.001 & $-0.457(p=0.000)$ \\
\hline Protein niệu & $7.0 \pm 6.00$ & $4.7 \pm 5.88$ & 0.002 & $0.226(p=0.014)$ \\
\hline pH niệu & $6.1 \pm 0.84$ & $6.5 \pm 0.65$ & 0.006 & $-0.241(p=0.009)$ \\
\hline Hemoglobin & $93.4 \pm 15.76$ & $108.3 \pm 21.57$ & 0.000 & $-0.204(p=0.028)$ \\
\hline Glucose & $5.4 \pm 1.45$ & $5.4 \pm 1.05$ & 0.431 & $-0.048(p=0.660)$ \\
\hline Protein & $51.4 \pm 9.95$ & $55.9 \pm 10.53$ & 0.060 & $-0.272(p=0.005)$ \\
\hline Albumin & $23.6 \pm 5.4$ & $26.4 \pm 6.27$ & 0.019 & $-0.131(p=0.159)$ \\
\hline Calci TP & $1.9 \pm 0.13$ & $2.0 \pm 0.20$ & 0.040 & $-0.091(p=0.387)$ \\
\hline Ferritin & $835.5 \pm 822.16$ & $842.5 \pm 831.34$ & 0.762 & $0.265(p=0.023)$ \\
\hline C3 & $0.48 \pm 0.212$ & $0.74 \pm 0.234$ & 0.000 & $-0.331(p=0.000)$ \\
\hline C4 & $0.11 \pm 0.086$ & $0.16 \pm 0.112$ & 0.010 & $-0.138(p=0.149)$ \\
\hline Anti ANA & $7.2 \pm 2.66$ & $4.9 \pm 2.95$ & 0.000 & $0.206(p=0.030)$ \\
\hline Anti-dsDNA & $96.7 \pm 58.63$ & $76.9 \pm 70.32$ & 0.054 & $0.102(p=0.283)$ \\
\hline ALEMP & $34.35 \pm 10.37$ & $34.40 \pm 13.60$ & 0.700 & $0.242(p=0.037)$ \\
\hline
\end{tabular}

Nhận xét: Acid uric máu có mối tương quan tuyến tính đồng biến với huyết áp tâm thu, creatinin máu, ferritin, protein niệu với $r=0.199$; $0.476 ; 0.265 ; 0.226(\mathrm{p}<0.05)$ và có mối tương quan nghịch với MLCT, pH niệu, hemoglobin, protein, C3 với $r=-0.457 ;-0.241 ;-0.204 ;-$ $0.272 ;-0.331(p<0.05)$. Acid uric có tương quan thuân với anti-ANA $r=0.206(p=0.03)$ nhưng không tương quan với yếu tố miễn dịch đặc hiệu
anti-dsDNA. Các chỉ số như albumin, calci máu, C4 không có tương quan với acid uric nhưng lại khác nhau có ý nghĩa thống kê giữa 2 nhóm tăng và không tăng acid uric với $p<0.05$.

ALĐMP và acid uric máu có tương quan đồng biến nhưng không có sự khác biệt có ý nghĩa ở 2 nhóm tăng và không tăng acid uric. Khi phân tích ALĐMP thành 2 nhóm tăng ALĐMP $>=40 \mathrm{mmHg}$ và không tăng $A L \boxminus M P<40 \mathrm{mmHg}$ thì nồng độ 
acid uric máu trung bình của 2 nhóm là $560.1 \pm 173.03$ và $464.3 \pm 131.31$, có sự khác biệt có ý nghĩa thống kê với $\mathrm{p}=0.018<0.05$.

\section{BÀN LUÂN}

Về đặc điểm chung, độ tuổi trung bình của nhóm nghiên cứu là $34.6 \pm 1.11$, chủ yếu xảy ra ở nữ giới trong độ tuổi sinh đẻ với tỷ lệ nam/nữ là $1 / 9.64$. Tỷ lệ tắng acid uric ở nữ giới cao hơn nam giới $(p<0.01)$ nhưng nồng độ acid uric ở 2 giới nam và nữ thì không có sự khác biệt $p>0.05$ [Bảng 1]. Do tăng acid uric ở phụ nữ tiền mãn kinh xác định khi nồng độ acid uric > 357 $\mu \mathrm{mol} / \mathrm{I}$ trong khi ở nam giới > 416 $\mu \mathrm{mol} / \mathrm{l}$.

Tràn dịch màng tim, tăng huyết áp, hội chứng thận hư và đặc biệt là thiếu máu đều chiếm tỷ lệ cao $>60 \%$ tương tự nghiên cứu của tác giả Nghiêm Trung Dũng [7]. Đặc biệt có sự khác biệt giữa 2 nhóm tăng acid uric và không tăng acid uric ở các triệu chứng này với $p<0.05$ [Biểu đồ 2]

Tỷ lệ tăng acid uric ở nghiên cứu chúng tôi là $75,2 \%$ với nồng độ trung bình là $463.60 \pm 13.03$. Tỷ lệ này cao hơn rất nhiều các nghiên cứu khác khi tăng acid uric được phát hiện ở 16,1\% bệnh nhân SLE và bệnh nhân viêm thận lupus ở giai đoạn CKD1-3 là 40,11\%[5]. Nồng độ creatinine tăng cao và MLCT thấp hơn có ý nghĩa thống kê ở nhóm tăng acid uric máu so với nhóm không tăng acid uric $(p<0,01)$. Chúng tôi thây rằng, giai đoạn CKD có liên quan chặt chẽ với tỷ lệ tăng acid uric, đặc biệt cao hơn trên bệnh nhân viêm thận lupus, điêu này cũng đã được chứng minh trước đây qua nghiên cứu năm 2017 của Liu [5]. Mức độ tăng của acid uric có liên quan đến chức năng của cầu thận và ống thận bị suy yếu. MLCT giảm dần, tăng khả năng tái hấp thu ở ống, suy giảm chức năng của ống đều làm nặng thêm tình trang tăng acid uric [5]. Như vậy tăng acid uric có mối liên quan chặt chẽ với bệnh thận mạn, không chỉ là hậu quả của suy thận, mà còn là nguyên nhân của tổn thương thận. Vì vậy trên lâm sàng, cần đánh giá và điều trị tăng acid uric trên bệnh nhân viêm thận lupus để hạn chế tổn thương và duy trì chức năng thận.

Trong số 46 bệnh nhân được sinh thiết thận của nghiên cứu có $78.3 \%$ bệnh nhân có tăng nồng độ acid uric. Từ kết quả nghiên cứu cho thây, tỷ lệ tăng acid uric ở class III, IV cao hơn có ý nghĩ̃a thống kê so với các class II, V, VI $(p<0.05)$ [Biểu đồ 3]. Nồng độ acid uric trung bình cũng có sự khác biệt giữa 2 class này. Điều này hoàn toàn phù hợp khi mà class III và IV là 2 nhóm tổn thương thận nặng và thường gặp trên lâm sàng.
Trên thực tế, tăng acid uric đã được chứng minh là gây tăng huyết áp thông qua một chuổi các sự kiện bao gồm giảm nitric oxide synthase, kích hoạt hệ thống angiotensin renin (RASS) và giảm tưới máu thâan, dẩn đến tăng sức cản mạch máu hệ thống, dẫn đến natri muộn tăng huyết áp nhạy cảm. Điều quan trọng là, mỗi tác dụng này đều được cải thiện bằng liệu pháp hạ thấp nồng độ acid uric [5].

Nghiên cứu của chúng tôi cho thây nồng độ acid uric có tương quan nghịch với C3 [Bảng 3], phù hợp với nghiên cứu trước đây [3],[5]. Giải thích cho điều này có thể là acid uric tăng cao trong VTL có thể kích hoạt C3 thông qua các con đường cổ điển và thay thế [3]. Sự lắng đọng của các sản phẩm kích hoạt bổ sung, lần lượt, làm nặng thêm tổn thương mô thận và sự phát triển của VTL.

Từ kết quả của Bảng 3, nồng độ acid uric có tương quan với nồng độ anti-ANA, hemoglobin, protein máu, calci huyết thanh, protein niệu. Kết quả này giống với nghiên cứu trước đây của Liu [5] và Okba [2], các chỉ số này đều có liên quan chặt chẽ với mức độ hoạt động của viêm thận lupus đã được chứng minh trong nghiên cứu của Nghiêm Trung Dũng [7]. Mức độ hoạt động bệnh trung bình của bệnh (tính theo thang điểm SLEDAI) ở nhóm tắng acid uric cao hơn nhóm không tăng acid uric $p<0.001$ [Bảng 2]. Trong nghiên cứu của chúng tôi, bệnh nhân tăng acid uric chỉ có mức độ hoạt động bệnh là manh $(50 \%)$ và rất mạnh $(50 \%)$, không có viêm thận lupus hoạt động nhẹ và trung bình. Kết quả có mối liên quan thuận giữa nồng độ acid uric và mức độ hoạt động bệnh (theo SLEDAI) với hệ số tương quan $r=0.388, p<0.001$ tương tự như nghiên cứu của Okba và cộng sự [2]. pH niệu có tương quan nghịch biến với nồng độ acid uric. Khi $\mathrm{pH}$ nước tiểu toan $<7.0$, thường gặp giảm thải urat ở ống thận do các acid hữu cơ bị tích Iũy sẽ canh tranh với urat khi thải qua ống thận.

ALĐMP và acid uric máu có mối tương quan đồng biến và acid uric cao hơn đáng kể ở những bệnh nhân bị tăng ALĐMP $(>40 \mathrm{mmHg})$ so với những người không tăng ALĐMP với với nồng độ trung bình $560.06 \pm 173.034$ và $464.25 \pm 131.308$ $(p<0.05)$. Kết quả này tương tự nghiên cứu của Kim năm 2015, người đã cho rằng áp lực động mạch phổi trong SLE hoạt động có thể thiết lập mổi trường thuận lợi để tạo acid uric và với việc sử dụng điểm cắt là $6,5 \mathrm{mg} / \mathrm{dL}(=464 \mu \mathrm{mol} / \mathrm{l})$, acid uric có độ chính xác hợp lý để dự đoán sự hiện diện của tăng ALĐMP ở bệnh nhân SLE nhiều như NT-proBNP [8]. 


\section{KẾT LUẬN VÀ KIẾN NGH!}

Tăng acid uric găp ở $75.2 \%$ các bênh nhân viêm thận lupus, dự báo tiến triển xấu của viêm thận lupus và các biến chứng của bệnh (như mức MLCT thấp hơn, thiếu máu hơn, huyết áp tăng, mức độ hoat động bênh SLEDAI cao hơn...). Việc giữ nồng độ acid uric thấp được khuyến cáo giúp tránh các biến chứng trong VTL và nồng độ acid uric huyết thanh nên được áp dung trong thực hành y tế khi đánh giá bênh nhân VTL. Mong rằng sau nghiên cứu này, việc đánh giá và điều trị tăng acid uric trên bệnh nhẩn viêm thận lupus sẽ được quan tâm và có thêm các nghiên cứu tìm hiểu sâu, đánh giá vai trò cuối cùng của tăng acid uric máu trong cơ chế bệnh sinh của viêm thận lupus và ý nghĩa của việc phát hiện sớm và điều trị tăng acid uric máu để cải thiện kết cục lâm sàng của viêm thận lupus.

\section{TÀI LIỆ THAM KHẢO}

1. Elera-Fitzcarrald $C_{\text {., }}$ Reátegui-Sokolova $C_{\text {. }}$ Gamboa-Cardenas R.V. và cộng sự. (2020). Serum uric acid is associated with damage in patients with systemic lupus erythematosus. Lupus Sci Med, 7(1).

2. Okba A.M., Amin M.M., và Reyad M.A.E.-D.\& M.A. (2019). Hyperuricemia as an independent predictor and prognostic factor in the development of lupus nephritis. Int J Clin Rheumatol, 14(3), 91.

3. Yang $Z$., Liang $Y$., Xi W. và công sứ. (2011) Association of serum uric acid with lupus nephritis in systemic lupus erythematosus. Rheumatol Int 31(6), 743-748.

4. Tsumuraya $Y_{\text {., Hirayama T., Tozuka E. và }}$ cộng sự. (2015). Impact of hyperuricaemia on the chronic kidney disease-associated risk factors in a community-based population. Nephrol Carlton Vic, 20(6), 399-404.

5. Liu S., Gong Y., Ren H. và cộng sự. (2017) The prevalence, subtypes and associated factors of hyperuricemia in lupus nephritis patients at chronic kidney disease stages 1-3. Oncotarget, 8(34), 57099-57108.

6. Chizyński K. và Rózycka M. (2005). [Hyperuricemia]. Pol Merkur Lek Organ Pol Tow Lek, 19 (113), 693-696.

7. Nghiêm Trung Dũng (2018). Nghiên cứu đánh gia mức độ hoạt động, tổn thương mô bênh hoc và tính đa hình thái gen STAT4; IRF5; CDKN1A trong viêm thận lupus. Luận Văn $Y$ Học, $<$ https://luanvanyhoc.com/nghien-cuu-danh-giamuc-do-hoat-dong-ton-thuong-mo-benh-hoc-vatinh-da-hinh-thai-gen-stat4-irf5-cdkn1a-trongviem-than-lupus/>, accessed: 04/10/2021.

8. Kim K.-J., Baek I.-W., Park Y.-J. và cộng sự. (2015). High levels of uric acid in systemic lupus erythematosus is associated with pulmonary hypertension. Int J Rheum Dis, 18(5), 524-532.

\section{BÁO CÁO MộT TRƯờNG HỢP BÊNNH NHÂN BI HộI CHỨNG BOSMA HIẾM GẶP TẠI BỆNH VIỆN CHỢ RẪY}

\section{TÓM TẮT}

Nhân một trường hợp bệnh nhân nữ 29 tuổi với chẩn đoán hội chứng BOSMA: tật không có mũi, kèm theo mắt nhỏ 2 bên, thị lực giảm, mất khứu giác, thở qua miệng, nói giọng không rõ và khẩu cái mềm ngắn, hàm trên kém phát triển. Các cấu trúc xoang cạnh mũi không phát triển (cốt hóa xương toàn bộ). Đây là một hội chứng hiếm gặp trên thế giới cũng như tại Việt Nam, hội chứng này có 3 đặc điểm chính: tật không mũi, kém phát triển các xoang cạnh mũi; tật mắt nhỏ và kém phát triển hệ thống sinh sản. Nhân trường hợp hiếm gặp này nhằm giới thiệu đến Bác sĩ Tai Mũi Họng hội chứng BOSMA.

Tư khóa: hội chứng Bosma, dị tật mũi bẩm sinh, tật không mũi

*Bênh viện Chơ Rẫy

Chịu trách nhiệm chính: Ngô Văn Công

Email: congtmh@gmail.com

Ngày nhận bài: 20.8.2021

Ngày phản biên khoa hoc: 19.10.2021

Ngày duyệt bài: 29.10.2021
Ngô Văn Công*

\section{SUMMARY \\ A CASE REPORT: BOSMA ARHINIA MICROPHTHALMIA SYNDROME AT CHO RAY HOSPITAL}

There is a female patient with 29 year's old. She have BOSMA syndrome from her child. She has congential arhinia, both eyes microphthalmia syndrome, loss vision, breath by mouth, voice by mouth, high-arched or cleft palate, hypoplastic maxilla. The paranasal sinus is calcificated and not growth. This syndrome is rarely happen in the world as well as Vietnam. It is defined by three major features: arhina and complete absence of the paranasal sinus; eye defects, and absent sexual maturation. This case report represent BOSMA syndrome to help ENT physician to understand this ones.

Keywords: BOSMA syndrome, congential arhinia syndrome, arhinia.

\section{GIỚl THIỆU}

Hội chứng Bosma là hội chứng được mô tả rất hiếm gặp được biểu hiện bởi tập hợp các dấu hiệu đặc trưng bởi tật không mũi bẩm sinh kèm 